\title{
Effects of different dietary protein and lipid levels on growth, feed utilization and body composition of red porgy (Pagrus pagrus) fingerlings
}

\author{
D. SCHUCHARDT, J.M. VERGARA，H. FERNÁNDEZ-PALACIOS，C.T. KALINOWSKI, \\ C.M. HERNÁNDEZ-CRUZ, M.S. IZQUIERDO \& L. ROBAINA \\ Grupo de Investigación en Acuicultura-GIA (ICCM \& ULPGC), Telde, Las Palmas, Spain
}

\begin{abstract}
Two feeding trials were conducted to determine the minimum dietary protein level producing maximum growth, and the optimum protein to energy ratio in diets for red porgy (Pagrus pagrus) fingerlings, respectively. In the first trial, six isoenergetic diets were formulated with protein levels ranging from 400 to $650 \mathrm{~g} \mathrm{~kg}^{-1}$ in increments of $50 \mathrm{~g} \mathrm{~kg}^{-1}$, and fed for 11 weeks to $2.8 \mathrm{~g}$ average initial weight fish. Weight gain, specific growth rate and feed efficiency were significantly higher with diets containing higher protein levels, when compared with dietary levels below $500 \mathrm{~g} \mathrm{~kg}^{-1}$. The highest protein efficiency ratios were obtained in fish fed $500 \mathrm{~g} \mathrm{~kg}^{-1}$ dietary protein. The minimum dietary protein level producing maximum fish growth was found to be $500 \mathrm{~g} \mathrm{~kg}^{-1}$. In the second trial, $15 \mathrm{~g}$ average initial weight fish were fed for 12 weeks, six diets containing three different lipid levels (100, 150 and $200 \mathrm{~g} \mathrm{~kg}^{-1}$ ) combined with two protein levels (450 and $500 \mathrm{~g} \mathrm{~kg}^{-1}$ ). Weight gain values increased when dietary lipids increased from 100 to $150 \mathrm{~g} \mathrm{~kg}^{-1}$, with a further decrease for $200 \mathrm{~g} \mathrm{~kg}^{-1}$ lipids in diets; the lowest fish growth being supported by $200 \mathrm{~g} \mathrm{~kg}^{-1}$ dietary lipids. Fish growth was significantly higher when dietary protein increased from 450 to $500 \mathrm{~g} \mathrm{~kg}^{-1}$. There was no evidence of a protein-sparing effect of dietary lipids. Liver protein and lipid contents were low when compared with other fish species. All diet assayed produced high liver glycogen accumulation. The recommended protein and lipid levels in diets for red porgy fingerlings were 500 and $150 \mathrm{~g} \mathrm{~kg}^{-1}$, respectively.
\end{abstract}

KEY WORDS: lipids, nutritional requirements, protein, red porgy

Received 28 April 2006, accepted 29 January 2007
Correspondence: Dominique Schuchardt, Instituto Canario de Ciencias Marinas (Taliarte), PO Box 56, Telde 35200, Las Palmas, Spain. E-mail: schuchardt@iccm.rcanaria.es

\section{Introduction}

Species diversification is considered a major approach for the sustainable development of Mediterranean aquaculture (Stephanis \& Divanach 1993; Papandroulakis et al. 2005). The red porgy has particular characteristics making it an appropriate candidate: high growth rate (Kentouri et al. 1994), ease to adapt to existing farming techniques for other widely cultured sparids such as gilthead seabream (Basurco \& Abellan 1999), and constantly high market prices all year around throughout the Mediterranean region (FEAP 2005). In addition, its life cycle has been closed under captive conditions (Hernández-Cruz et al. 1990, 1997, 1999; Kentouri et al. 1994; Conides et al. 2000; Conides \& Glamuzina 2001; Mihelakakis et al. 2001; Pavlidis et al. 2003; Mylonas et al. 2004).

Studies on juveniles culture fed with commercial diets for gilthead seabeam showed high feed conversion rates (3.0-3.5) (Divanach et al. 1993), and in 1994 around 130 tonnes were commercially produced in Cyprus and Greece, using also commercial gilthead seabream diets and resulting in poor growth rates and an abnormal dark external colour or the fish (Stephanou et al. 1995; Klios et al. 1997). There have been also some preliminary attempts to formulate specific diets for this species (Kalinowski et al. 2005). However, no published data up to date are available on the basic nutritional requirements of the red porgy.

The optimal dietary protein levels found for different sparid species have been reported to be around $500 \mathrm{~g} \mathrm{~kg}^{-1}$ (Yone et al. 1974; Takeuchi et al. 1991; Vergara et al. 1996a). In addition, the current trend in fish feed production is to increase the lipid content in diets to spare proteins, to improve feed 


\begin{tabular}{|c|c|c|c|c|c|c|}
\hline Diet protein/lipid $\left(\mathrm{g} \mathrm{kg}^{-1}\right)$ & $400 / 150$ & $450 / 150$ & $500 / 150$ & $550 / 150$ & $600 / 150$ & $650 / 150$ \\
\hline \multicolumn{7}{|l|}{ Ingredients } \\
\hline Fish meal $^{1}$ & 518 & 592 & 666 & 739 & 813 & 887 \\
\hline Fish oil & 83 & 75 & 65 & 58 & 50 & 42 \\
\hline Cornstarch & 354 & 289 & 223 & 157 & 92 & 32 \\
\hline Vitamin premix ${ }^{2}$ & 20 & 20 & 20 & 20 & 20 & 20 \\
\hline Mineral premix ${ }^{3}$ & 20 & 20 & 20 & 20 & 20 & 20 \\
\hline C.M.cellulose ${ }^{4}$ & 5 & 5 & 5 & 5 & 5 & 5 \\
\hline \multicolumn{7}{|l|}{ Nutrient content (dry matter) } \\
\hline Crude protein $\left(\mathrm{g} \mathrm{kg}^{-1}\right)$ & 391 & 439 & 493 & 553 & 605 & 652 \\
\hline Total lipids $\left(\mathrm{g} \mathrm{kg}^{-1}\right)$ & 147 & 150 & 146 & 152 & 149 & 147 \\
\hline Ash $\left(\mathrm{g} \mathrm{kg}^{-1}\right)$ & 78 & 86 & 95 & 104 & 128 & 133 \\
\hline Moisture $\left(\mathrm{g} \mathrm{kg}^{-1}\right)$ & 99 & 139 & 83 & 111 & 116 & 79 \\
\hline $\operatorname{NFE}^{5}\left(\mathrm{~g} \mathrm{~kg}^{-1}\right)$ & 384 & 325 & 265 & 191 & 117 & 67 \\
\hline $\mathrm{GE}^{6}\left(\mathrm{MJ} \mathrm{kg}^{-1}\right)$ & 19.93 & 19.98 & 20.03 & 20.08 & 20.13 & 20.17 \\
\hline$P: E^{7}\left(g \mathrm{MJ}^{-1}\right)$ & 19.64 & 22.00 & 24.63 & 27.52 & 30.06 & 32.34 \\
\hline
\end{tabular}

Table 1 Composition (fed basis) and proximate analysis of the diets fed $\left(\mathrm{g} \mathrm{kg}^{-1}\right)$ to $P$. pagrus fingerlings in trial 1

${ }^{1}$ Proximate analysis ( $\mathrm{g} \mathrm{kg}^{-1} \mathrm{dry} \mathrm{wt}$ ): crude protein: 743, total lipids: 121, ash: 123.

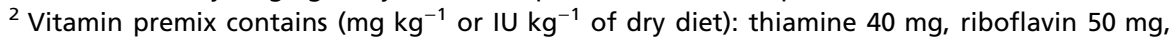
pyridoxine $40 \mathrm{mg}$, calcium pantothenate $117 \mathrm{mg}$, nicotinic acid $200 \mathrm{mg}$, biotin $1 \mathrm{mg}$, folic acid $10 \mathrm{mg}$, cyanocobalamin $0.5 \mathrm{mg}$, choline chloride $2700 \mathrm{mg}$, inositol $600 \mathrm{mg}$, ascorbic acid $1000 \mathrm{mg}$, alpha tocopherol $250 \mathrm{mg}$, menadione $20 \mathrm{mg}$, cholecalciferol $2000 \mathrm{lU}$, ethoxyquin $100 \mathrm{mg}$, retinol acetate $5000 \mathrm{IU}$.

${ }^{3}$ Mineral premix contains ( $\mathrm{g} \mathrm{kg}^{-1}$ of dry diet): calcium orthophosphate $1.60 \mathrm{~g}$, calcium carbonate $4 \mathrm{~g}$, ferrous sulphate $1.5 \mathrm{~g}$, magnesium sulphate $1.6 \mathrm{~g}$, potassium phosphate $2.8 \mathrm{~g}$, sodium phosphate $1 \mathrm{~g}$, aluminium sulphate $0.02 \mathrm{~g}$, zinc sulphate $0.24 \mathrm{~g}$, copper sulphate $0.20 \mathrm{~g}$, manganese sulphate $0.08 \mathrm{~g}$, potassium iodate $0.02 \mathrm{~g}$. Both premixes were prepared with $\alpha$-cellulose to include at $2 \%$ of the experimental diets.

${ }^{4}$ Carboxy methyl cellulose (sodium salt).

${ }^{5}$ Nitrogen free extract, calculated as $1000-\left(\right.$ protein + lipid + ash) $\mathrm{g} \mathrm{kg}^{-1}$.

${ }^{6}$ Calculated gross energy content (Brafield, 1985).

${ }^{7}$ Protein to energy ratio in $\mathrm{g} \mathrm{MJ}^{-1}$.

conversion and to decrease the amount of nitrogen waste produced by the fish. Most of the research in this area has been done with salmonid species (Hillestad \& Johnsen 1994; Weatherup et al. 1997; Helland \& Grisdale-Helland 1998; Hemre \& Sandnes 1999; Lee \& Kim 2001; Gélineau et al. 2002; Nordgarden et al. 2002), whereas less information exists on warmwater marine species such as sparids (Takeuchi et al. 1991; Ballestrazzi \& Lanari 1996; Tibaldi et al. 1996; Vergara et al. 1996b, 1999; Pérez et al. 1997; Company et al. 1999; Peres \& Oliva Teles 1999; Lupatsch et al. 2001; Boujard et al. 2004; Skalli et al. 2004). The present work aimed to investigate protein and lipids levels required for an optimal growth of fingerlings from this species.

\section{Materials and methods}

\section{Fish and feeding}

Trial 1 Six experimental diets were prepared containing a range of dietary protein from 400 to $650 \mathrm{~g} \mathrm{~kg}^{-1}$ by replacing fish meal with cornstarch in order to produce isoenergetic diets. Dietary lipid level was fixed at $150 \mathrm{~g} \mathrm{~kg}^{-1}$ in all diets.
Dietary protein and lipids sources were Norwegian fish meal (LT 95) and capelin oil (Norsalmoil; Norsildmel, Bergen, Norway), respectively. Data for ingredients and chemical compositions are shown in Table 1.

Red porgy fingerlings of $2.8 \mathrm{~g}$ initial average body weights were anaesthetized (chlorobutanol $200 \mathrm{mg} \mathrm{L}^{-1}$; at $70 \mathrm{~mL} /$ $100 \mathrm{~L}$ sampling tanks), weighed and randomly stocked in 100-L fibreglass tanks in triplicate groups of 17 fish. All tanks were supplied with continuous flow of natural seawater. Average water temperature and dissolved oxygen concentration along the experimental period (11 weeks) were $21.8^{\circ} \mathrm{C} \pm 0.35$ and $6.4 \mathrm{mg} \mathrm{L}^{-1} \pm 0.62$, respectively. A controlled photoperiod of $14 \mathrm{~h} \mathrm{light} / 10 \mathrm{~h}$ dark was maintained during the trial. Fish were hand fed until apparent satiation, five times a day, 6 days a week.

Trial 2 Six experimental diets were prepared in order to obtain three different dietary lipid levels $\left(100,150\right.$ and $\left.200 \mathrm{~g} \mathrm{~kg}^{-1}\right)$ combined with two dietary protein levels ( 450 and $500 \mathrm{~g} \mathrm{~kg}^{-1}$ ). Dietary protein and lipid sources were Norwegian fish meal (LT 95) and capeling oil, respectively. Diet ingredient contents and chemical composition are shown in Table 2. 


\begin{tabular}{|c|c|c|c|c|c|c|}
\hline Diet (protein/lipids) $\left(\mathrm{g} \mathrm{kg}^{-1}\right)$ & $450 / 100$ & $450 / 150$ & $450 / 200$ & $500 / 100$ & $500 / 150$ & $500 / 200$ \\
\hline \multicolumn{7}{|l|}{ Ingredients } \\
\hline Fish meal ${ }^{1}$ & 646 & 646 & 646 & 729 & 729 & 729 \\
\hline Fish oil & 32 & 82 & 132 & 23 & 73 & 123 \\
\hline Cornstarch & 277 & 227 & 177 & 203 & 153 & 103 \\
\hline Vitamin premix ${ }^{2}$ & 20 & 20 & 20 & 20 & 20 & 20 \\
\hline Mineral premix ${ }^{3}$ & 20 & 20 & 20 & 20 & 20 & 20 \\
\hline C.M.cellulose $e^{4}$ & 5 & 5 & 5 & 5 & 5 & 5 \\
\hline \multicolumn{7}{|l|}{ Nutrient content (DM) } \\
\hline Crude protein $\left(\mathrm{g} \mathrm{kg}^{-1}\right)$ & 482 & 477 & 471 & 534 & 529 & 523 \\
\hline Total lipids $\left(\mathrm{g} \mathrm{kg}^{-1}\right)$ & 111 & 147 & 195 & 96 & 147 & 200 \\
\hline Ash $\left(\mathrm{g} \mathrm{kg}^{-1}\right)$ & 81 & 78 & 76 & 75 & 83 & 85 \\
\hline Moisture $\left(\mathrm{g} \mathrm{kg}^{-1}\right)$ & 83 & 78 & 75 & 87 & 91 & 89 \\
\hline $\mathrm{NFE}^{5}\left(\mathrm{~g} \mathrm{~kg}^{-1}\right)$ & 326 & 298 & 258 & 295 & 240 & 192 \\
\hline $\mathrm{GE}^{6}\left(\mathrm{MJ} \mathrm{kg}^{-1}\right)$ & 21.29 & 22.13 & 23.23 & 21.39 & 22.38 & 23.51 \\
\hline$P: E^{7}\left(g J^{-1}\right)$ & 22.64 & 21.55 & 20.27 & 24.96 & 23.64 & 22.24 \\
\hline
\end{tabular}

Table 2 Composition (fed basis) and proximate analysis of the diets fed $\left(\mathrm{g} \mathrm{kg}^{-1}\right)$ to $P$. pagrus fingerlings in trial 2

${ }^{1}$ Proximate analysis ( $\mathrm{g} \mathrm{kg}^{-1} \mathrm{dry} \mathrm{wt}$ ): crude protein: 743, total lipids: 121, ash: 123.

${ }^{2}$ Vitamin premix contains ( $\mathrm{mg} \mathrm{kg}^{-1}$ or IU kg ${ }^{-1}$ of dry diet): thiamine $40 \mathrm{mg}$, riboflavin $50 \mathrm{mg}$, pyridoxine $40 \mathrm{mg}$, calcium pantothenate $117 \mathrm{mg}$, nicotinic acid $200 \mathrm{mg}$, biotin $1 \mathrm{mg}$, folic acid $10 \mathrm{mg}$, cyanocobalamin $0.5 \mathrm{mg}$, choline chloride $2700 \mathrm{mg}$, inositol $600 \mathrm{mg}$, ascorbic acid $1000 \mathrm{mg}$, alpha tocopherol $250 \mathrm{mg}$, menadione $20 \mathrm{mg}$, cholecalciferol $2000 \mathrm{IU}$, ethoxyquin $100 \mathrm{mg}$, retinol acetate $5000 \mathrm{IU}$.

${ }^{3}$ Mineral premix contains ( $\mathrm{g} \mathrm{kg}^{-1}$ of dry diet): calcium orthophosphate $1.60 \mathrm{~g}$, calcium carbonate $4 \mathrm{~g}$, ferrous sulphate $1.5 \mathrm{~g}$, magnesium sulphate $1.6 \mathrm{~g}$, potassium phosphate $2.8 \mathrm{~g}$, sodium phosphate $1 \mathrm{~g}$, aluminium sulphate $0.02 \mathrm{~g}$, zinc sulphate $0.24 \mathrm{~g}$, copper sulphate $0.20 \mathrm{~g}$, manganese sulphate $0.08 \mathrm{~g}$, potassium iodate $0.02 \mathrm{~g}$. Both premixes were prepared with $\alpha$-cellulose to include at $2 \%$ of the experimental diets.

${ }^{4}$ Carboxy methyl cellulose (sodium salt).

${ }^{5}$ Nitrogen free extract, calculated as $1000-$ (protein + lipid + ash) $\mathrm{g} \mathrm{kg}^{-1}$.

${ }^{6}$ Calculated gross energy content (Brafield, 1985).

${ }^{7}$ Protein to energy ratio in $\mathrm{g} \mathrm{MJ}^{-1}$.

Red porgy fingerlings of initial average body weight $15 \mathrm{~g}$ were anaesthetized (chlorobutanol $200 \mathrm{mg} \mathrm{L}^{-1}$; at $70 \mathrm{~mL} /$ $100 \mathrm{~L}$ sampling tanks), weighed and randomly stocked in 500L fibreglass tanks in triplicate groups of 50 fish. All tanks were supplied with continuous flow of natural seawater of $6 \mathrm{~L} \mathrm{~min}{ }^{-1}$. Average water temperature and dissolved oxygen concentration along the experimental period (12 weeks) were $22.4 \pm 0.05^{\circ} \mathrm{C}$ and $6.2 \pm 0.07 \mathrm{mg} \mathrm{L}^{-1}$, respectively. A controlled photoperiod with artificial light of $13 \mathrm{~h}$ light $/ 11 \mathrm{~h}$ dark was maintained during the trial. Fish were hand fed until apparent satiation, three times a day, 6 days a week, due to the bigger size of fish.

\section{Samples and analysis}

Twelve fish at the start of each experiment and three per tank at the end were killed by an overdose of chlorobutanol and stored at $-20{ }^{\circ} \mathrm{C}$ for subsequent chemical analysis. Besides, fish were individually weighed at the beginning, after 5 weeks and at the end of the experiment.
Dry matter and ash in feeds and fish samples were determined gravimetrically after drying for $24 \mathrm{~h}$ until constant weight, at $105^{\circ} \mathrm{C}$ and after combustion for $24 \mathrm{~h}$ at $450{ }^{\circ} \mathrm{C}$, respectively. Crude protein $(\mathrm{N} \times 6.25)$ and lipid contents were determined by Kjeldahl (AOAC 1995) and Folch (Folch et al. 1957) methods, respectively.

Red porgy livers from three fish per tank at the end of the experiment were fixed in $10 \%$ buffered formaldehyde for histological evaluations. Livers were then dehydrated in ethanol series, embedded in paraffin, serially sectioned at 4-5 m, and stained with haematoxylin and eosin (H\&E), and periodic acid Schiff-reactive haematoxylin (PAS-Hx) (Garcia Del Moral 1993). The PAS-Hx was used to selectively stain glycogen.

One- and two-way analysis (independent variable protein and lipid) of variance (ANOVA), and 5\% level probability (Tukey 95\%) were used to compare data $(P<0.05)$, which are presented as mean $\pm \mathrm{SD}$ of three replicate groups (Sokal \& Rolf 1995). The broken line test was also used to estimate minimum dietary protein level supporting optimal growth (Zeitoun et al. 1976). 
Table 3 Mean growth performance and feed conversion of $P$. pagrus fingerlings fed the experimental diets in trial 1

\begin{tabular}{lcccccc}
\hline Diet (protein/lipid) $\left(\mathrm{g} \mathrm{kg}^{-1}\right)$ & $400 / 150$ & $450 / 150$ & $500 / 150$ & $550 / 150$ & $600 / 150$ & $650 / 150$ \\
\hline Average initial weight (g) & $2.62 \pm 1.07$ & $2.66 \pm 0.98$ & $2.77 \pm 1.17$ & $2.70 \pm 0.97$ & $2.74 \pm 1.1$ & $2.66 \pm 0.99$ \\
Average final weight (g) & $15^{\mathrm{a}} \pm 4$ & $18^{\mathrm{b}} \pm 4$ & $23^{\mathrm{c}} \pm 6$ & $22^{\mathrm{bc}} \pm 7$ & $23^{\mathrm{c}} \pm 6$ & $23^{\mathrm{c}} \pm 7$ \\
Weight gain (\% of initial weight) & $451^{\mathrm{a}} \pm 60$ & $581^{\mathrm{b}} \pm 41$ & $714^{\mathrm{c}} \pm 34$ & $724^{\mathrm{c}} \pm 76$ & $712^{\mathrm{c}} \pm 50$ & $771^{\mathrm{c}} \pm 70$ \\
$\mathrm{SGR}^{1}$ & $2.28^{\mathrm{a}} \pm 0.14$ & $2.56^{\mathrm{ab}} \pm 0.08$ & $2.83^{\mathrm{bc}} \pm 0.01$ & $2.81^{\mathrm{bc}} \pm 0.16$ & $2.81^{\mathrm{bc}} \pm 0.10$ & $2.88^{\mathrm{c}} \pm 0.11$ \\
$\mathrm{FCR}^{2}$ & $1.67^{\mathrm{b}} \pm 0.12$ & $1.59^{\mathrm{b}} \pm 0.17$ & $1.20^{\mathrm{a}} \pm 0.1$ & $1.20^{\mathrm{a}} \pm 0.09$ & $1.12^{\mathrm{a}} \pm 0.02$ & $1.05^{\mathrm{a}} \pm 0.09$ \\
PER $^{3}$ & $1.54 \pm 0.12$ & $1.43 \pm 0.17$ & $1.66 \pm 0.22$ & $1.51 \pm 0.11$ & $1.46 \pm 0.05$ & $1.45 \pm 0.11$ \\
\hline
\end{tabular}

Values in the same row with no superscripts are not significantly different $(P<0.05)$.

${ }^{1} \mathrm{SGR}=\left(\left(\log _{\mathrm{e}}\right.\right.$ average final weight $-\log _{\mathrm{e}}$ average initial weight $) /$ no days $) \times 100$.

${ }^{2} \mathrm{FCR}=$ feed consumption (g)/weight gain $(\mathrm{g})$.

${ }^{3} \mathrm{PER}=$ weight gain $(\mathrm{g}) /$ protein intake $(\mathrm{g})$.

\section{Results and discussion}

\section{Trial 1}

Growth response of red porgy fingerlings fed with different experimental diets is shown in Table 3. Final body weights were significantly higher $(P<0.05)$ in fish fed diets with protein levels $500,550,600$ and $650 \mathrm{~g} \mathrm{~kg}^{-1}$ than in those fed protein levels of 400 and $450 \mathrm{~g} \mathrm{~kg}^{-1}$. Similarly, weight gain and food conversion ratios were significantly poorer $(P<0.05)$ with diets containing protein levels below $500 \mathrm{~g} \mathrm{~kg}^{-1}$. Dietary protein levels below $500 \mathrm{~g} \mathrm{~kg}^{-1}$ also produced lower specific growth rates (SGR), the values of fish fed protein level $400 \mathrm{~g} \mathrm{~kg}^{-1}$ was significantly lower $(P<0.05)$ than fish fed with protein levels of 500, 550, 600 and $650 \mathrm{~g} \mathrm{~kg}^{-1}$. Protein efficiency ratios (PER) values were highest in fish fed $500 \mathrm{~g} \mathrm{~kg}^{-1}$ protein, but not significantly different from other fish treatments (Table 3).

Among fish fed the lower protein contents, the linear increase in weight gain, together with the decrease in food conversion ratios suggested a possible limitation of certain amino acid contents in those diets to completely promote growth. The broken line test applied to weight gain with different dietary protein levels showed a value of minimum dietary protein level supporting optimal growth of $508 \mathrm{~g} \mathrm{~kg}^{-1}$ (Fig. 1), which is within the range of levels found for different sparid species, such as common dentex (Dentex dentex) (Cardenete et al. 1999), Japanese seabream (Takeuchi et al. 1991) and gilthead seabream (Vergara et al. 1996a). Dietary protein levels above $500 \mathrm{~g} \mathrm{~kg}^{-1}$ did not show an additional effect on either weight gain or feed conversion, this might be explained as dietary energy needed to deaminate and excrete excess absorbed amino acids (Cowey et al. 1972; Teng et al. 1978; Shi et al. 1988).

The average muscle protein content showed a similar trend to that of PER, with the highest values corresponding to fish fed diets with 450,500 and $550 \mathrm{~g} \mathrm{~kg}^{-1}$ protein, being signifi-

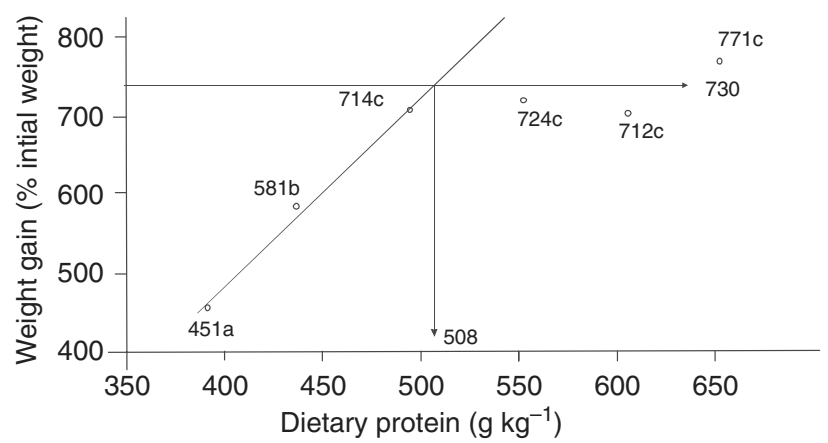

Figure 1 Broken line test applied to weight gain ( $\%$ of initial weight) with different dietary protein levels in trial 1.

cantly different from $(P<0.05)$ fish fed diets with 400,600 and $650 \mathrm{~g} \mathrm{~kg}^{-1}$ protein (Table 4), suggesting again that fish treatment with protein level $400 \mathrm{~g} \mathrm{~kg}^{-1}$, with the lowest protein level, was unable to meet the requirement for the optimal protein synthesis, whereas dietary protein levels above $550 \mathrm{~g} \mathrm{~kg}^{-1}$ lead to a reduced muscle protein synthesis. In general, fish fed protein levels between 400 and $500 \mathrm{~g} \mathrm{~kg}^{-1}$ tended to show higher muscle lipid contents than those fed either higher or lower protein levels. This could be due to enhanced lipogenesis from either high protein or carbohydrate levels in these diets. Liver protein and lipid contents were low when compared with other fish species (red porgy average $\mathrm{P} / \mathrm{L}$ $370 / 210 \mathrm{~g} \mathrm{~kg}^{-1}$ and for other species 500/380 $\mathrm{g} \mathrm{kg}^{-1}$ ) (Tibaldi et al. 1996; Robaina et al. 1997; Dias et al. 1998; Company et al. 1999; Santinha et al. 1999; Boujard et al. 2004), and liver protein content showed an increment as dietary protein increased (Table 4). In general, fish diets with high levels of protein tend to promote fatty acids or glycogen synthesis derived from proteins (Wilson 1989), while diets with high levels of carbohydrate tend to reduce protein digestibility and increase liver glycogen concentration and liver size (NRC, 1993; Krogdahl et al. 2005). However, these effects could not be observed in this trial, all different treatments leading to a high liver glycogen accumulation. 


\begin{tabular}{|c|c|c|c|c|c|c|c|}
\hline & \multirow[b]{2}{*}{ Initial } & \multicolumn{6}{|c|}{ Diet (protein/lipid) $\left(\mathrm{g} \mathrm{kg}^{-1}\right)$} \\
\hline & & $400 / 150$ & $450 / 150$ & $500 / 150$ & $550 / 150$ & $600 / 150$ & $650 / 150$ \\
\hline \multicolumn{8}{|c|}{ Liver composition } \\
\hline Moisture & 653 & 613 & 603 & 592 & 608 & 613 & 601 \\
\hline Protein & 358 & $226^{a}$ & $248^{a}$ & $271^{\mathrm{ab}}$ & $293^{a b}$ & $312^{\mathrm{bc}}$ & $342^{c}$ \\
\hline Lipids & 201 & $235^{\mathrm{ab}}$ & $209^{a}$ & $290^{\mathrm{b}}$ & $236^{\mathrm{ab}}$ & $203^{a}$ & $246^{\mathrm{ab}}$ \\
\hline \multicolumn{8}{|c|}{ Muscle composition } \\
\hline Moisture & 749 & $722^{a}$ & $743^{b}$ & $733^{a b}$ & $749^{c}$ & $734^{\mathrm{ab}}$ & $736^{a b}$ \\
\hline Protein & 825 & $745^{\mathrm{b}}$ & $819^{d}$ & $811^{d}$ & $821^{d}$ & $723^{a}$ & $779^{c}$ \\
\hline Lipids & 82 & $92^{b}$ & $90^{\mathrm{b}}$ & $94^{\mathrm{b}}$ & $75^{\mathrm{a}}$ & $91^{\mathrm{b}}$ & $78^{\mathrm{a}}$ \\
\hline
\end{tabular}

Table 4 Liver and muscle composition of $P$. pagrus fingerlings fed the experimental diets in trial $1\left(\mathrm{~g} \mathrm{~kg}^{-1}\right.$ dry weight basis)

Values in the same row with no superscripts are not significantly different $(P<0.05)$.

A moderate vacuolization of hepatocyte was shown in the fish livers both at the start of the experiment (fed with commercial gilthead seabream diets: $450 \mathrm{~g} \mathrm{~kg}^{-1}$ protein, $210 \mathrm{~g} \mathrm{~kg}^{-1}$ lipids) (Fig. 2a), and in fish fed diets with $\mathrm{P} / \mathrm{L}$ $400 / 150$ and $450 / 150 \mathrm{~g} \mathrm{~kg}^{-1}$ (Fig. 2c). The hepatocyte size of livers from fish fed diets with protein levels of 600 and $650 \mathrm{~g} \mathrm{~kg}^{-1}$ was smaller than other experimental groups, and the hepatocyte cytoplasm showed high acidophilia (Fig. 2e). A clear lipidic degeneration of hepatocytes in the fish liver at the start of the experiment was found (Fig. 2b). In general, and independently of diets, all fish livers showed high glycogen accumulation in hepatocytes cytoplasm, revealed as the eosinophile material found with the PAS technique (Fig. 2d,f). This elevated glycogen accumulation in hepatocytes, to a higher extent than that observed for gilthead seabream (Robaina et al. 1997), could partially explain the low liver protein and lipid contents found in the proximate analysis. Similar high liver glycogen accumulation has been observed in Japanese seabream (Pagrus major), with values up to $360 \mathrm{~g} \mathrm{~kg}^{-1}$ liver glycogen (Jeong et al. 1991).

The results from this trial suggest an optimum protein level in diets for $P$. pagrus fingerlings of $500 \mathrm{~g} \mathrm{~kg}^{-1}$ when hand fed to satiation, and for a fixed dietary lipid level of $150 \mathrm{~g} \mathrm{~kg}^{-1}$. Similar results have been found for other sparids (Millikin 1983; Alliot \& Pastoureaud 1984; Takeuchi et al. 1991; Tibaldi et al. 1996; Vergara et al. 1996a; Cardenete et al. 1999).

\section{Trial 2}

Red porgy fingerlings fed different protein and lipid levels showed the best response in the final body weight $(P<0.05)$ and SGR $(P<0.05)$ when fed diet with $\mathrm{P} / \mathrm{L} 500 / 150 \mathrm{~g} \mathrm{~kg}^{-1}$ (Table 5). No significant differences were found in total ingested feed or PER between different treatments, although for each protein level ingested feed tended to decrease with increase in dietary lipids. PER was improved for each dietary protein level when dietary lipids increased from 100 to
$150 \mathrm{~g} \mathrm{~kg}^{-1}$, followed by a decrease for diets containing $200 \mathrm{~g} \mathrm{~kg}^{-1}$ lipids (Table 5). Both dietary protein and lipid levels, as well as their interactions significantly affected final body weight $(P<0.05)$ and SGR $(P<0.05)$. Thus, diets containing $500 \mathrm{~g} \mathrm{~kg}^{-1}$ protein produced higher final body weights and SGR than diets with $450 \mathrm{~g} \mathrm{~kg}^{-1}$ protein, regardless of the lipid levels, and diets containing 100 and $150 \mathrm{~g} \mathrm{~kg}^{-1}$ lipids produced highest final body weights and SGR, irrespective of the protein levels (Table 6). The fact that diets with $200 \mathrm{~g} \mathrm{~kg}^{-1}$ lipid produced the lowest values could be due to a poorer capability of this species to digest dietary lipids, when compared with other sparid species (Arantzamendi 2002). Average muscle and liver protein and lipid contents were not significantly affected by different treatments (Table 7), although there was a trend towards a decrease in muscle lipid when dietary protein content increased from 450 to $500 \mathrm{~g} \mathrm{~kg}^{-1}$ in all dietary lipid levels. As in the previous trial, liver protein and lipid contents were low when compared with other fish species (Takeuchi et al. 1991; Tibaldi et al. 1996; Robaina et al. 1997; Peres \& Oliva Teles 1999; Lupatsch et al. 2001; Skalli et al. 2004), and for dietary lipid levels of 100 and $150 \mathrm{~g} \mathrm{~kg}^{-1}$, both liver protein and lipid contents tended to increase as dietary protein increased from 450 to $500 \mathrm{~g} \mathrm{~kg}^{-1}$.

Liver histology showed areas of esteatosis, migration of hepatocyte nucleus, together with a high amount of lipidic vacuoles in fish livers both at the start of the experiment (fed with commercial gilthead seabream diets: $400 \mathrm{~g} \mathrm{~kg}^{-1}$ protein, $210 \mathrm{~g} \mathrm{~kg}^{-1}$ lipids), and in fish fed with $\mathrm{P} / \mathrm{L} 450 / 150 \mathrm{~g} \mathrm{~kg}^{-1}$. Eosinophile material was present in hepatocytes cytoplasm in all treatments, with a higher intensity in livers of fish fed diets with $\mathrm{P} / \mathrm{L} 450 / 200$ and $500 / 150 \mathrm{~g} \mathrm{~kg}^{-1}$. High glycogen accumulation was apparent in hepatocytes cytoplasm of all fish livers, without differences between different treatments. This effect, also observed in trial 1, suggests that red porgy has a higher capability to store glycogen in liver than other sparid species such as gilthead seabream (Robaina et al. 1997). 

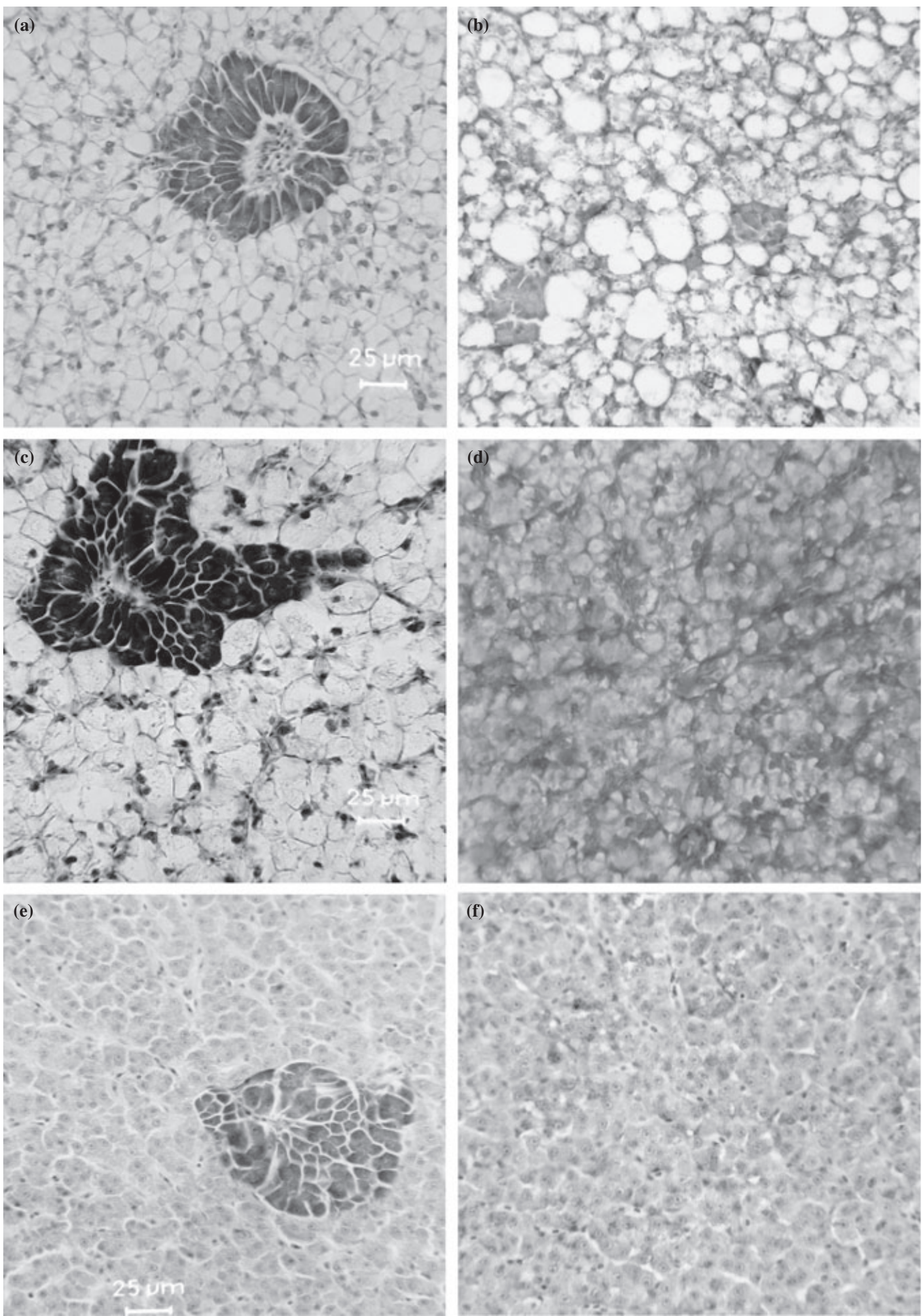

Figure 2 Livers of red porgy fed different experimental diets (trial 1). (a) Initial livers. Hepatocytes with migration of nuclei (H\&E). (b) Initial livers. Increased cytoplasm vacuolation and severe lipid vacuoles accumulation (PAS-Hx). (c) Diet 2. Hepatocytes with migration of the nuclei (H\&E). (d) Diet 2. Hepatocytes with significant glycogen accumulation in the cytoplasm (PAS-Hx). (e) Diet 5. Hepatocytes with large centrally located nuclei and acidophile cytoplasma (H\&E). (f) Diet 5. Hepatocytes with glycogen deposition in the cytoplasm. 
Table 5 Mean growth performance and food conversion of $P$. pagrus fingerlings fed the experimental diets in trial 2

\begin{tabular}{lcccrrr}
\hline Diet (protein/lipid) $\left(\mathrm{g} \mathrm{kg}^{-1}\right)$ & $450 / 100$ & $450 / 150$ & $450 / 200$ & $500 / 100$ & $500 / 150$ & $500 / 200$ \\
\hline Average initial weight (g) & $15.23 \pm 0.49$ & $15.88 \pm 0.20$ & $15.31 \pm 0.68$ & $15.40 \pm 0.99$ & $15.47 \pm 0.19$ & $15.69 \pm 0.76$ \\
Average final weight (g) & $60.2^{\mathrm{ab}} \pm 13.4$ & $61.5^{\mathrm{ab}} \pm 11.8$ & $56.6^{\mathrm{a}} \pm 10.9$ & $64.9^{\mathrm{c}} \pm 15.3$ & $73.9^{\mathrm{d}} \pm 3.6$ & $58.8^{\mathrm{a}} \pm 15.0$ \\
Weight gain (\% of initial weight) & $295^{\mathrm{abc}} \pm 11$ & $287^{\mathrm{ab}} \pm 18$ & $269^{\mathrm{a}} \pm 5$ & $341^{\mathrm{cde}} \pm 29$ & $377^{\mathrm{e}} \pm 4$ & $315^{\mathrm{abcd}} \pm 20$ \\
Total ingested food (g) & $2214.7 \pm 157$ & $1980.9 \pm 108$ & $2120.5 \pm 139$ & $2237.0 \pm 142$ & $2178.5 \pm 68.3$ & $2017.2 \pm 31.4$ \\
SGR $^{1}$ & $1.65^{\mathrm{abc}} \pm 0.05$ & $1.61^{\mathrm{ab}} \pm 0.07$ & $1.55^{\mathrm{a}} \pm 0.02$ & $1.76^{\mathrm{bcd}} \pm 0.08$ & $1.86^{\mathrm{d}} \pm 0.01$ & $1.69^{\mathrm{abc}} \pm 0.07$ \\
FCR $^{2}$ & $1.71^{\mathrm{abc}} \pm 0.28$ & $1.64^{\mathrm{abc}} \pm 0.16$ & $1.78^{\mathrm{bc}} \pm 0.08$ & $1.40^{\mathrm{abc}} \pm 0.03$ & $1.25^{\mathrm{ab}} \pm 0.14$ & $1.95^{\mathrm{c}} \pm 0.13$ \\
PER $^{3}$ & $1.92 \pm 0.78$ & $2.23 \pm 0.18$ & $2.07 \pm 0.10$ & $2.38 \pm 0.06$ & $2.71 \pm 0.28$ & $1.76 \pm 0.09$ \\
\hline
\end{tabular}

Values in the same row with no superscripts are not significantly different $(P<0.05)$.

${ }^{1} \mathrm{SGR}=\left(\left(\log _{\mathrm{e}}\right.\right.$ average final weight $-\log _{\mathrm{e}}$ average initial weight $) /$ days $) \times 100$.

${ }^{2} \mathrm{FCR}=$ feed consumption (g)/weight gain $(\mathrm{g})$.

${ }^{3} \mathrm{PER}=$ weight gain $(\mathrm{g}) /$ protein intake $(\mathrm{g})$.

Table 6 Factorial analysis of variance (two-way) of the effect of dietary protein and lipid levels $\left(\mathrm{g} \mathrm{kg}^{-1}\right)$ on final body weight (FBW) and specific growth rate (SGR) in trial 2

\begin{tabular}{|c|c|}
\hline & Mean FBW \\
\hline \multicolumn{2}{|c|}{ Dietary protein level ${ }^{1}(P=0.0000)$} \\
\hline 450 & $59.42^{\mathrm{a}}$ \\
\hline 500 & $69.27^{b}$ \\
\hline \multicolumn{2}{|c|}{ Dietary lipid level $^{1}(P=0.0000)$} \\
\hline 100 & $64.97^{\mathrm{ab}}$ \\
\hline 150 & $67.39^{\mathrm{b}}$ \\
\hline \multirow[t]{2}{*}{200} & $62.95^{\mathrm{a}}$ \\
\hline & Mean SGR \\
\hline \multicolumn{2}{|c|}{ Dietary protein level ${ }^{2}(P=0.0000)$} \\
\hline 450 & $1.60^{\mathrm{a}}$ \\
\hline 500 & $1.78^{\mathrm{b}}$ \\
\hline \multicolumn{2}{|c|}{ Dietary lipid level ${ }^{2}(P=0.0058)$} \\
\hline 100 & $1.73^{\mathrm{b}}$ \\
\hline 150 & $1.75^{\mathrm{b}}$ \\
\hline 200 & $1.66^{\mathrm{a}}$ \\
\hline
\end{tabular}

${ }^{1}$ Interactions between protein and lipid levels $(P=0.076)$.

${ }^{2}$ Interactions between protein and lipid levels $(P=0.023)$.

Table 7 Liver and muscle composition of $P$. pagrus fingerlings fed the experimental diets in trial $2\left(\mathrm{~g} \mathrm{~kg}^{-1}\right.$ dry weight basis)

\begin{tabular}{lccccccc}
\hline \multicolumn{7}{c}{ Diet (protein/lipid) $\left(\mathrm{g} \mathrm{kg}^{-1}\right)$} \\
\cline { 2 - 7 } & \multicolumn{1}{c}{ Initial $400 / 100$} & $400 / 150$ & $400 / 200$ & $500 / 100$ & $500 / 150$ & $500 / 200$ \\
\hline \multicolumn{7}{l}{ Liver composition } \\
Moisture 645 & 667 & 647 & 652 & 651 & 650 & 650 \\
Protein & 358 & 348 & 337 & 413 & 374 & 360 & 396 \\
Lipids & 201 & 165 & 199 & 246 & 291 & 218 & 182 \\
Muscle composition & & & & & \\
Moisture 759 & 769 & 758 & 753 & 759 & 758 & 758 \\
Protein & 846 & 889 & 877 & 837 & 828 & 833 & 873 \\
Lipids & 82 & 80 & 104 & 83 & 74 & 54 & 63 \\
\hline
\end{tabular}

Values in the same row with no superscripts are not significantly different $(P<0.05)$.
The result from this trial suggests optimum protein and lipid levels in diets for red porgy fingerlings of 500 and $150 \mathrm{~g} \mathrm{~kg}^{-1}$, respectively, when hand fed to satiation. No protein-sparing effect due to dietary lipids could be detected in trial 2, as fish growth values increased when dietary lipids increased from 100 to $150 \mathrm{~g} \mathrm{~kg}^{-1}$, with a further decrease for $200 \mathrm{~g} \mathrm{~kg}^{-1}$ lipids in diets. Similar results to our experiment were found in common dentex (Cardenete et al. 1999). Although in various sparids the authors have obtained a protein-sparing effect due to dietary lipids, such as, the D. dentex (Tibaldi et al. 1996; Skalli et al. 2004), and S. aurata (Vergara et al. 1996b; Company et al. 1999; Santinha et al. 1999; Lupatsch et al. 2001).

\section{Acknowledgement}

This study has been financed by the CICYT (project Mar 97-0327-C02-01/02).

\section{References}

Alliot, E. \& Pastoureaud, A. (1984) Covering the food requirements of sea bass and sea bream. Aquaculture of sea bass and sparids. L'aquaculture du Bar et des Sparides, pp. 337-349.

AOAC. (1995) Official Methods of Analysis, 16th edn. Association of Official Analytical Chemist, Washington, DC.

Arantzamendi, L. (2002) Efecto de los lípidos dietéticos sobre la producción. la composición y la actividad lipolítica en peces comerciales. Doctoral Thesis, Universidad de Las Palmas de Gran Canaria.

Ballestrazzi, R. \& Lanari, D. (1996) Growth, body composition and nutrient retention efficiency of growing sea bass (Dicentrarchus labrax L.) fed fish oil or fatty acid Ca salts. Aquaculture, 139, 101-108.

Basurco, B. \& Abellan, E. (1999) Finfish diversification in the context of Mediterranean marine fish farming development. In: Marine Finfish Diversification: Current Situation and Prospects in Mediterranean Aquaculture (Abellan, E. \& Basurci, B. eds), Vol. 24B, pp. 9-25. Cah. Option Mediterrannéenes, FAO, Études de recherche. 
Boujard, T., Gélineau, A., Covés, D., Corraze, G., Dutto, G., Gasset, E. \& Kaushik, S. (2004) Regulation in feed intake, growth, nutrient and energy utilisation in European sea bass (Dicentrarchus labrax) fed high fat diet. Aquaculture, 231, 529-545.

Brafield, A.E. (1985) Laboratories studies on energy budgets. In: Fish energetics. New Perspective (Tytler, P. \& Calow, P. eds), pp. 257281. Croom Helm, London and Sydney.

Cardenete, G., Abellán, E., Hidalgo, M.C., Skalli, A. \& Arizcun, M. (1999) Relación proteína energía en dietas para juveniles de dentón (Dentex dentex). Cah. Opt. Méditerranéennes, 22, $141-151$.

Company, R., Calduch-giner, J.A., Perez-sanchez, J. \& Kaushik, S.J. (1999) Protein sparing effect of dietary lipids in common dentex (Dentex dentex): a comparative study with sea bream (Sparus aurata) and sea bass (Dicentrarchus labrax). Aquat. Living Resour., 12, 23-30.

Conides, A.J. \& Glamuzina, B. (2001) Study on the early development and growth of the red porgy, Pagrus pagrus with emphasis on the mass mortalities observed during this phase. Scientia Marina (Barcelona), 65, 193-200.

Conides, A.J., Nengas, I. \& Klaoudatos, S.D. (2000) Current advances in new finfish species aquaculture of the National Centre for Marine Research (Greece). Recent advances in Mediterranean aquaculture finfish species diversification. Proceedings of the Seminar of the CIHEAM network and Technology of Aquaculture in the Mediterranean (TECAM), jointly organized by CIHEAM and FAO, Zaragosa, Spain. Cah. Options Mediterr., 47, 365-369.

Cowey, C.B., Pope, J.A., Adron, J.W. \& Blair, A. (1972) Studies on the nutrition of marine flatfish. The protein requirement of plaice (Pleuronectes platessa). J. Nutr., 28, 447-456.

Dias, J., Alvarez, M.J., Diez, A., Arzel, J., Corraze, G., Bautista, J.M. \& Kaushik, S.J. (1998) Regulation of hepatic lipo genesis by dietary protein/energy in juvenile European sea bass (Dicentrarchus labrax). Aquaculture, 161, 169-186.

Divanach, P., Kentouri, M., Charalambakis, G., Pouget, F. \& Sterioti, A. (1993) Comparison of growth performance of six Mediterranean fish species reared under intensive farming conditions in Crete (Greece), in raceways with the use of self-feeders. Prod. Environ. Qual., 18, 285-297.

FEAP (2005 Federation of European Aquaculture Producers. http:// www.feap.info/redporgy/default_en.asp

Folch, J., Lees, M. \& Stanley, G.H.S. (1957) A simple method for the isolation and purification of total lipids from animal tissues. J. Biol. Chem., 226, 497-509.

Garcia Del Moral, R. (1993) Laboratorio de anatomía patológica, 1st edn. Interamericana, McGraw-Hill, Madrid, Spain.

Gélineau, A., Bolliet, V., Corraze, G. \& Boujard, T. (2002) The combined effects of feeding time and dietary fat levels on feed intake, growth and body composition in rainbow trout. Aquat. Living Resour., 15, 225-230.

Helland, S.J. \& Grisdale-Helland, B. (1998) The influence of replacing fish meal in the diet with fish oil on growth, feed utilization and body composition of Atlantic salmon (salmo salar) during the smoltification period. Aquaculture, 162, 1-10.

Hemre, G.I. \& Sandnes, K. (1999) Effect of dietary lipid level on muscle composition in Atlantic salmon Salmo salar. Aquacult. Nutr., 5, 9-16.

Hernández-Cruz, C.M., Fernández Palacios, H. \& Fernández Palacios, J.E. (1990) Estudio preliminar del desarrollo embrionario y larvario del bocinegro. Pagrus pagrus (Pisces. Sparidae). en cultivo. Vieraea, 19, 215-224.

Hernández-Cruz, C.M., Salhi, M., Bessonart, M., Fernández-Palacios, H., Valencia, A. \& Izquierdo, M.S. (1997) Primeras experi- encias de cultivo larvario de bocinegro (Pagrus pagrus) (Osteichthyes, Sparidae). En: Actas del VI Congreso Nacional de Acuicultura (MAPA), 507-508.

Hernández-Cruz, C.M., Salhi, M., Bessonart, M., Izquierdo, M.S., Gonzalez, M.M. \& Fernandez-Palacios, H. (1999) Rearing techniques for red porgy (Pagrus pagrus) during larval development. Aquaculture, 179, 489-497.

Hillestad, M. \& Johnsen, F. (1994) High-energy/low-protein diets for Atlantic salmon: effects on growth, nutrient retention and slaughter quality. Aquaculture, 124, 109-116.

Jeong, K.S., Toshio, T. \& Watanabe, T. (1991) Improvement of nutritional quality of carbohydrate ingredients by extrusion process in diets of red sea bream. Nippon Suisan Gakkaishi, 57, 1543-1549.

Kalinowski, C.T., Robaina, L.E., Fernandez-Palacios, H., Schuchardt, D. \& Izquierdo, M.S. (2005) Effect of different carotenoid sources and their dietary levels on red porgy (Pagrus pagrus) growth and skin colour. Aquaculture, 244, 223-231.

Kentouri, M., O'neil, D., Divanach, P. \& Charalambakis, G. (1994) A study of the quantitative water requirement of red porgies Pagrus pagrus L. Pisces: Sparidae. during early on growing under self feeding conditions. Aquaculture, 25, 741-752.

Klios, P., Kiritsis, S. \& Katribusas, N. (1997) Larval-rearing and growth of the red porgy (Pagrus pagrus) in the Riopesca hatchery (Greece). Hydrobiologia, 358, 321-325.

Krogdahl, Å., Hemre, G.I. \& Mommsen, T.P. (2005) Carbohydrates in fish nutrition: digestion and absorption in postlarval stages. Aquacult. Nutr., 11, 103-122.

Lee, S.M. \& Kim, K.D. (2001) Effects of dietary protein and energy levels on the growth, protein utilization and body composition of juvenile masu salmon (Oncorhynchus masou Brevoort). Aquacult. Res., 32, 39-45.

Lupatsch, I., Kissil, G.W., Sklan, D. \& Pfeffer, E. (2001) Effects of varying dietary protein and energy supply on growth, body composition and protein utilization in gilthead sea bream (Sparus aurata L.). Aquaculture, 7, 71-80.

Mihelakakis, A., Yoshimatsu, T. \& Tsolkas, C. (2001) Spawning in captivity and early life history of cultured red porgy, Pagrus pagrus. Aquaculture, 199, 333-352.

Millikin, M.R. (1983) Interactive effects of dietary protein and lipid on growth and protein utilization of age-0 striped bass. Trans. Am. Fish. Soc., 112, 185.

Mylonas, C.C., Papadaki, M. \& Divanach, P. (2004) Evaluation of egg production and quality in the Mediterranean red porgy (Pagrus pagrus) during two consecutive spawning seasons. Aquaculture, 232, 637-649.

Nordgarden, U., Hemre, G.-I. \& Hansen, T. (2002) Growth and body composition of Atlantic salmon (Salmo salar L.) parr and smolt fed diets varying in protein and lipid contents. Aquaculture, 207, 65-78.

NRC (National Research Council) (1993) Nutrient Requirements of Fish. The National Academies Press, Washington, DC, 114 pp.

Papandroulakis, N.T., Mylonas, C.C., Maingot, E. \& Divanach, P. (2005) First results of greater amberjack (Seriola dumerili) larval rearing in mesocosm. Aquaculture, 250, 155-161.

Pavlidis, M., Angellotti, L., Papandroulakis, N. \& Divanach, P. (2003) Evaluation of transportation procedures on water quality and fry performance in red porgy (Pagrus pagrus) fry. Aquaculture, 218, 187-202.

Peres, H. \& Oliva Teles, A. (1999) Effect of dietary lipid level on growth performance and feed utilization by European sea bass (Dicentrarchus labrax). Aquaculture, 179, 325-334. 
Pérez, L., Gonzalez, H., Jover, M. \& Fernández-Carmona, J. (1997) Growth of European sea bass fingerlings (Dicentrarchus labrax) fed extruded diets containing varying levels of protein. lipid and carbohydrate. Aquaculture, 156, 183-193.

Robaina, L., Moyano, F.J., Izquierdo, M.S., Socorro, J., Vergara, J.M. \& Montero, D. (1997) Corn gluten and meat and bone meals as protein sources in diets for gilthead sea bream (Sparus aurata): nutritional and histological implications. Aquaculture, 157, 347-359.

Santinha, P.J.M., Medale, F., Corraze, G. \& Gomes, E.F.S. (1999) Effects of the dietary protein/lipid ratio on growth and nutrients utilization in gilthead seabream (Sparus aurata L). Aquacult. Nutr., 5, 147-156.

Shi, W., Shan, J. \& Liu, M. (1988) Study on the optimum demand of protein by blunt-nose bream (Megalobrama amblycephala). Proc. Aquacult. Int. Congr., 62, 92-95.

Skalli, A., Hidalgo, M.C., Abellán, E., Arizcun, M. \& Cardenete, G. (2004) Effects of the dietary protein/lipid ratio on growth and nutrient utilization in common dentex (Dentex dentex L) at different growth stages. Aquaculture, 235, 1-11.

Sokal, R.R. \& Rolf, F.J. (1995) Biometry. The Principal and Practice of Statistics in Biological Research, 3rd edn. W.H. Freeman \& Co., New York, 419 pp.

Stephanis, J. \& Divanach, P. (1993) Farming of Mediterranean Finfish species. In: From Discovery to Commercialization (Carrillo, M., Dahle, L., Moreales, J., Sorgeloss, P., Svennevig, N. \& Wyban, J. eds) pp. 290-297. European Aquaculture Society, Spec. Publ., No. 19, Oostende, Belgium.

Stephanou, D., Georgiou, G. \& Shoukri, E. (1995) Reproduction and larval rearing of the common sea bream (Pagrus pagrus), an experimental culture. Dep-of-Fisheries (Nicosia, Cyprus) En: Cahiers Options, 16, 79-87.

Takeuchi, T., Shiina, Y. \& Watanabe, T. (1991) Suitable protein and lipid levels in diets for fingerlings of red sea bream (Pagrus major). Nippon Suisan Gakkaishi, 57, 293-299.
Teng, S., Chua, T. \& Lim, P. (1978) Preliminary observation on the dietary protein requirement of estuary grouper. Epinephelus salmoides Maxwell cultured in floating net-cages. Aquaculture, 15, 257-271.

Tibaldi, E., Beraldo, P., Volpelli, L.A. \& Pinosa, M. (1996) Growth response of juvenile dentex (Dentex dentex L.) to varying protein level and protein to lipid ratio in practical diets. Aquaculture, 139, 91-99.

Vergara, J.M., Palacios, H.F., Robaina, L., Jauncey, K., De La Higuera, M. \& Izquierdo, M.S. (1996a) The effects of varying dietary protein level on the growth feed efficiency, protein utilization and body composition of gilthead sea bream fry. Fish. Sci., 62, 620-623.

Vergara, J.M., Robaina, L., Izquierdo, M. \& De La Higuera, M. (1996b) Protein sparing effect of lipids in diets for fingerlings of gilthead sea bream. Fish. Sci., 62, 624-628.

Vergara, J.M., López-Calero, G., Robaina, L., Caballero, M.J., Montero, D., Izquierdo, M.S. \& Aknes, A. (1999) Growth feed utilization and body lipid content of gilthead sea bream (Sparus aurata) fed increasing lipid levels and fish meals of different quality. Aquaculture, 179, 35-44.

Weatherup, R.N., Mccracken, K.J., Foy, R., Rice, D., Mckendry, J., Mairs, R.J. \& Hoey, R. (1997) The effect of dietary fat content on performance and body composition of farmed rainbow trout (Oncorhynchus mykiss). Aquaculture, 151, 173-184.

Wilson, R.P. (1989) Amino acids and proteins. In: Fish Nutrition, 2nd edn (Cowey, C.B., Mackie, A.M. \& Bell, J.G. eds), pp. 111145. Academic Press, New York.

Yone, Y., Sakamoto, S. \& Furuichi, M. (1974) Studies on nutrition of Red Sea bream 9. The basal diet for nutrition studies. Rep. Fish. Res. Lab. Kyushu Univ., 2, 13-24.

Zeitoun, I.H., Ullrey, D.E., Magee, W.T., Gill, J.L. \& Bergen, W.G. (1976) Quantifying nutrient requirements of fish. J. Fish. Res. Board Can., 33, 167-172. 